\title{
Influence of modern preparations on soybean crop productivity in the conditions of forest steppe of the Middle Volga region
}

\author{
Vasily G. Vasin, Ramis N. Saniev*, Alexey V. Vasin, Nikolai A. Prosandeev, and Alexey N. Burunov \\ Samara State Agrarian University, Kinel, 446442, Russia
}

\begin{abstract}
The article presents the results of scientific research on the growth-stimulating preparations in the pre-sowing treatment of soybean seeds and crops according to the development phases in the foreststeppe zone of the Middle Volga. It contains the results of the 2016-2018 research with an assessment of indicators of plant safety, photosynthetic activity and soybean yield in different treatment options by growth factors. The two-component preparations in pre-sowing seed treatment contribute to better soybean germination up to $78.12 \%$. The pre-sowing treatment of seeds with Risotorphine and Raykat Start preparations forms the maximum leaf area. Comparing three years, we can say that the leaves work more productively in the variants with the use of Risotorphine and Raykat Start in pre-sowing treatment. Weather conditions in 2018 allowed soybean crops to form a high yield. The yield level was in the range of 1.48 $1.98 \mathrm{t} /$ ha. Inoculation of seeds with Raykat Start followed by crops treatment in the phase of 3-5 leaves and budding allowed achieving maximum yield for all years of research. After treating the seeds with Raykat Start, the maximum grain yield was 1.40 t/ha with a double-treatment of crops by microfertilizing mixture Megamix Profi in a phase of 3-5 leaves and budding.
\end{abstract}

\section{Introduction}

The lack of complete protein in the diet of modern man is a major nutritional problem. Each living organism consists of proteins that are involved in the most important chemical processes supporting the body's vital functions. The need to further increase the production of vegetable protein lies with an increase in the population of the globe and its direct use in human nutrition [1-4].

Currently, the protein problem is very relevant to agricultural production. Legumes are the main source of vegetable protein. Among leguminous crops, soybean is one of the most popular leguminous crops in the world. Its seeds are rich in proteins up to $41 \%$, in fats up to $21 \%$, and have an almost perfect amino acid composition protein, polyunsaturated fatty acids ( $\omega-3$ and $\omega-6)$, much water- and fat-soluble vitamins, especially vitamin $E$, the most important natural antioxidant, minerals and other components that have the beneficial biological effect for the human body.

Soybean is a universal food and feed crop. It is a unique and valuable agricultural crop due to its rich diverse chemical composition of seeds and its versatile use in fodder, food and technical purposes. Its popularity resulted from the biological characteristics, as well as the biochemical composition of the grain which allows using in many industries, including culinary, medicine, chemical, food industry, feed production [5-12].

\section{Materials and methods}

\subsection{Objects of study}

In the experiments we used the following biological products and micronutrient mixtures:

Risotorphine (biofertilizer) is an inoculant based on nodule bacteria (nitrogen-fixing bacteria) which can enter into symbiosis with leguminous plants propagated in sterile peat with $0.25 \mathrm{~mm}$ slices. The smallest particles contribute to better adhesion to the seeds. In its appearance, it is a dark-colored mass with a moisture content of $40-50 \%$, enriched with carbohydrates, vitamins, macro and microelements of a stimulating effect for pre-sowing treatment of legume seeds.

Raykat Start is a liquid organic fertilizer produced on the basis of seaweed extract with the content of active amino acids, polysaccharides, cytokinins, balanced by the composition of macro and microelements $\mathrm{N}-4 \%$, $\mathrm{P}_{2} \mathrm{O}_{5}-8 \%, \quad \mathrm{~K}_{2} \mathrm{O}-3 \%, \quad \mathrm{Fe}-0.1 \%$, $\mathrm{Zn}-0.2 \%$, B- $0.03 \%$, including free amino acids - 4\%, polysaccharides - $5 \%$, cytokinins $-0.05 \%$.

Kelik Mix is a boron chelate in liquid form for correcting the deficiency of trace elements of physiologically verified concentration, the composition includes $\mathrm{Fe}-5 \%, \mathrm{Mn}-2 \%, \mathrm{Zn}-0.37 \%, \mathrm{Cu}-0.19 \%, \mathrm{~B}-$ $0.65 \%$, Mo- $0.18 \%$, chelating agent is EDTA.

Aminocat 10 is a preparation based on a seaweed extract. This is a plant growth factor with a quick effect

\footnotetext{
* Corresponding author: saniev.ssaa@ mail.ru
} 
that increases the resistance of plants to adverse conditions. It contains N-3\%, P2O5-1\%, K2O-1\%, free amino acids $-30 \%$, including glutamic acid- $7.2 \%$, lysine$4.2 \%$, glycine- $3.6 \%$.

Raykat Growth is a liquid organic-mineral fertilizer produced on a seaweed extract with the addition of macro and microelements, vitamins. This factor is specially designed to improve the stage of development and growth of new plant tissues. It contains $\mathrm{N}-6 \%, \mathrm{P}_{2} \mathrm{O}_{5-}$ $4 \%, \mathrm{~K}_{2} \mathrm{O}-3 \%, \mathrm{Fe}-0.1 \%$, Mn- $0.07 \%$, Zn-0.02\%, B- $0.03 \%$, $\mathrm{Cu}-0.01 \%$, Mo-0.1\%, free amino acids - 4\%, seaweed extract $-5 \%$, cytokinins - $0.05 \%$, vitamin complex $0.2 \%$.

Megamix Profi is a mineral fertilizer for root and foliar top dressing with high nitrogen content, micro and macroelements, it provides nitrogen and microelements nutrition during the growing season. It compensates for increased nutritional needs in key developmental phases. It contains N-6 g / L, Mg-15 g / L, S-29 g / L, Cu-7 g / L, Zn-14 g / L, Fe-3 g / L, Mn-3.5 g / L, B-1.7 g / 1, Mo-4.6 $\mathrm{g} / 1, \mathrm{Co}-1 \mathrm{~g} / 1, \mathrm{Cr}-0.3 \mathrm{~g} / 1, \mathrm{Se}-0.1 \mathrm{~g} / 1, \mathrm{Ni}-0.1 \mathrm{~g} / 1$.

The aim of the study is to increase soybean productivity in the forest-steppe of the Middle Volga

The objective of the research is to assess the parameters of plant safety, photosynthetic activity of plants in crops (leaf area, photosynthetic potential, net productivity of photosynthesis), soybean yield in crops, depending on the use of growth-stimulating preparations in seed treatment and during vegetation.

\subsection{Research Methods}

The studies were conducted on the experimental field of the Department of Crop Production and Agriculture of the Samara State Agrarian University in 2016-2018. The soil of the experimental plot was ordinary chernozem, residual carbonate, medium humus, medium-heavy, heavy-loamy with a content of easily hydrolyzable nitrogen of $105-127 \mathrm{mg} / \mathrm{kg}$, mobile phosphorus of 130 $152 \mathrm{mg} / \mathrm{kg}$ and exchange potassium of $311-324 \mathrm{mg} / \mathrm{kg}$, PH 5.8. Humidification was natural.

Agricultural technology was common for the zone. We sowed with the AMAZONED9-25 seeder in the usual ordinary way with a seeding rate of 750 thousand germinating seeds per 1 ha. We harvested separately in the phase of full ripeness.

Three-factor experience on studying the methods of pre-sowing seed treatment and sowing of Samer 1 soybean varieties included the following seed treatment options: Risotorphine (strain 634b), Risotorphine (strain 634b) plus 11 / t of Raykat Start, 11 / t of Raykat Start (factor A), as well as options treatment of crops with preparations: without treatment (control), treatment with 0.51 / ha of Kelik Mix, 0.51 / ha of Aminocat 10 plus 0.5 $1 /$ ha of Raykat Growth, 0.51 / ha of Megamix Profi (factor B). The treatment time includes the phase of 3-5 sheets, the phase of 3-5 leaves and budding, the budding phase (factor C) (Table 2).

We conducted the studies considering the field experiment methodology of B.A. Dospekhov (1985) and the guidelines for conducting field experiments with feed crops of the All-Russian Research Institute of Feed named after Williams (1987, 1997).

\section{Results}

When sowing seeds with high germination, the number of seedlings is always less than the number of seeds sown. Part of the seeds in the field does not germinate at all, although some germinate, but their sprouts cannot break through the soil layer and die. When sowing seeds of early ripening varieties with a sowing rate of 700 750 thousand germinating seeds per 1 ha, the optimal plant stand density of seedlings is $550-600$ thousand / ha.

On average, over three years of research, the stand density was in the range of 57.5-56.61 pcs / $\mathrm{m}^{2}$ with seedling completeness of 76.67-78.12\%. The best option for the use of preparations in pre-sowing seed treatment is Risotorphine and Raykat Start preparations with stand density of $58.61 \mathrm{pcs} / \mathrm{m}^{2}$ and seedling completeness of $78.12 \%$. Therefore, the use of a mixture of Risotorphine and Raykat Start preparations in pre-sowing seed treatment contributes to better seedling completeness (Table 1).

Table 1. Completeness of soybean plant seedlings depending on pre-sowing seed treatment 2016-2018

\begin{tabular}{|c|c|c|}
\hline Seed treatment & $\begin{array}{c}\text { Plant stand } \\
\text { density, pcs } / \mathrm{m}^{2}\end{array}$ & $\begin{array}{c}\text { Completeness of } \\
\text { seedlings \% }\end{array}$ \\
\hline Risotorphine & $\mathbf{5 7 . 5 3}$ & $\mathbf{7 6 . 6 7}$ \\
\hline $\begin{array}{c}\text { Risotorphine }+ \\
\text { Raykat Start }\end{array}$ & $\mathbf{5 8 . 6 1}$ & $\mathbf{7 8 . 1 2}$ \\
\hline Raykat Start & $\mathbf{5 7 . 8 4}$ & $\mathbf{7 7 . 0 7}$ \\
\hline
\end{tabular}

The optimal sowing structure is one of the main factors for obtaining a high yield. The productiveness per unit area is determined by the number of plants and the mass of one plant. The safety of crops for harvesting is an important indicator that directly affects the value of the future crop.

The study revealed that the preservation of soybean plants was quite high and this indicator was in the range of $60.37-62.65 \%$ with the use of seed pre-treatment. The best option for pre-sowing seed treatment is seed treatment with Raykat Start, where the safety is $62.65 \%$. The treatment with growth factors during vegetation also affected the safety of the plants and according to the options it is within $60.03 \%-63.31 \%$.

The use of Megamix Profi and mixtures of Aminocat $10+$ Raykat Growth preparations in the processing of crops during the inoculation of seeds with Raykat Start increases the safety of plants to $63.20 \%$ and $63.31 \%$. The best option in terms of treatment during the vegetation period is the treatment in the budding phase with a mixture of Aminocat + Raykat Growth preparations, where the safety rate by the time of harvesting was $64.28 \%$ (Table 2). 
Table 2. Number and safety of soybean plants by the time of harvesting, depending on the pre-sowing treatment of seeds and treatments with growth factors for the 2016-2018 vegetation period.

\begin{tabular}{|c|c|c|c|c|c|c|}
\hline \multirow[b]{2}{*}{$\begin{array}{l}\text { Seed } \\
\text { treatment }\end{array}$} & \multicolumn{2}{|c|}{ Treatment during vegetation } & \multirow{2}{*}{$\begin{array}{c}\text { Number of } \\
\text { plants. } \\
\text { thousand } \\
\text { pcs/ha }\end{array}$} & \multicolumn{3}{|c|}{ Plant safety. \% } \\
\hline & Preparations & Treatment period & & $\begin{array}{l}\text { in terms of } \\
\text { treatment } \\
\text { of crops }\end{array}$ & $\begin{array}{l}\text { on average } \\
\text { for seed } \\
\text { treatment }\end{array}$ & $\begin{array}{l}\text { on average } \\
\text { for crop } \\
\text { treatment }\end{array}$ \\
\hline \multirow{10}{*}{ 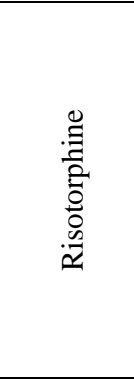 } & Without treatment & - & 34.93 & 61.63 & \multirow{10}{*}{61.05} & 61.63 \\
\hline & \multirow{3}{*}{ Kelik Mix } & 3-5 leaves & 35.47 & 62.45 & & \multirow{3}{*}{61.40} \\
\hline & & 3-5 leaves+budding & 35.60 & 61.87 & & \\
\hline & & budding & 35.43 & 59.87 & & \\
\hline & \multirow{3}{*}{$\begin{array}{c}\text { Aminocat + Raykat } \\
\text { Growth }\end{array}$} & 3-5 leaves & 34.27 & 60.29 & & \multirow{6}{*}{60.53} \\
\hline & & 3-5 leaves+budding & 35.60 & 61.17 & & \\
\hline & & budding & 36.23 & 61.64 & & \\
\hline & \multirow{3}{*}{ Megamix Profi } & 3-5 leaves & 34.57 & 60.05 & & \\
\hline & & 3-5 leaves+budding & 35.63 & 60.40 & & \\
\hline & & budding & 35.60 & 61.15 & & \\
\hline \multirow{10}{*}{ 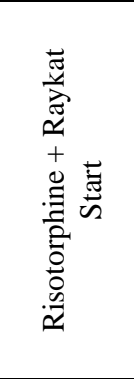 } & Without treatment & - & 34.99 & 60.21 & \multirow{10}{*}{60.37} & 60.21 \\
\hline & \multirow{3}{*}{ Kelik Mix } & 3-5 leaves & 36.27 & 61.30 & & \multirow{3}{*}{61.13} \\
\hline & & 3-5 leaves+budding & 36.30 & 61.63 & & \\
\hline & & budding & 35.60 & 60.47 & & \\
\hline & \multirow{3}{*}{$\begin{array}{c}\text { Aminocat + Raykat } \\
\text { Growth }\end{array}$} & 3-5 leaves & 34.90 & 59.96 & & \multirow{6}{*}{60.36} \\
\hline & & 3-5 leaves+budding & 36.30 & 60.57 & & \\
\hline & & budding & 34.23 & 58.46 & & \\
\hline & \multirow{3}{*}{ Megamix Profi } & 3-5 leaves & 34.50 & 58.58 & & \\
\hline & & 3-5 leaves+budding & 36.70 & 62.14 & & \\
\hline & & budding & 35.97 & 60.37 & & \\
\hline \multirow{10}{*}{ 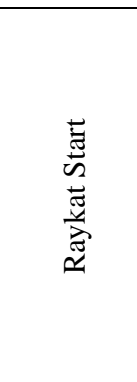 } & Without treatment & - & 34.67 & 60.82 & \multirow{10}{*}{62.65} & 60.82 \\
\hline & \multirow{3}{*}{ Kelik Mix } & 3-5 leaves & 35.93 & 61.40 & & \multirow{3}{*}{62.03} \\
\hline & & 3-5 leaves+budding & 36.97 & 62.81 & & \\
\hline & & budding & 35.23 & 61.89 & & \\
\hline & \multirow{3}{*}{$\begin{array}{l}\text { Aminocat }+ \text { Raykat } \\
\text { Growth }\end{array}$} & 3-5 leaves & 36.63 & 63.31 & & \\
\hline & & 3-5 leaves+budding & 36.27 & 62.33 & & 63.31 \\
\hline & & budding & 36.97 & 64.28 & & \\
\hline & \multirow{3}{*}{ Megamix Profi } & 3-5 leaves & 37.50 & 63.43 & & \multirow{3}{*}{63.20} \\
\hline & & 3-5 leaves+budding & 37.40 & 63.33 & & \\
\hline & & budding & 37.00 & 62.85 & & \\
\hline
\end{tabular}

The study of the influence of individual technological methods on the growth and development of crops, as a rule, requires the observations of characteristics of photosynthetic activity in crops. This question is crucial, since changing the conditions of plant growth inevitably, directly or indirectly, affects the formation of the crop. The main indicators characterizing the production process in crops are leaf area, photosynthetic potential and net photosynthesis productivity.

Numerous studies of A.A. Nichiporovich and his colleagues have shown that plant productivity is closely related to growth and photosynthesis, which are two cardinal physiological processes. The creation of a photosynthetic apparatus of high activity is the first condition for obtaining good crop productivity. The second no less important condition is the creation of a photosynthetic apparatus of sufficient size, that is, obtaining optimal long-term preservation of the leaf area (Kefeli V.I., 1991).

On average over the years of research, the maximum area of soybean leaves was formed during the flowering phase. The best result was due to the use of Risotorphine and the mixture of Risotorphine and Raykat Start preparations in the pre-sowing treatment of seeds using the vegetative microfertilizer mixture Megamix Profi with processing in the phase of 3-5 leaves with an indicator of 52.4 and 53.1 thousand $\mathrm{m}^{2}$ / ha, as well as on the option of the seed treatment with Raykat Start followed by vegetation treatment with a two-component solution Aminocat 10 and Raykat Growth in the phase of budding with an indicator of 52.5 thousand $\mathrm{m}^{2} /$ ha (Table 3).

By the phase of the bean formation, the leaf area decreased, it also depended on the options of treatments. In the variant with seed inoculation with Risotorphine, followed by treatment of the crops with the Aminocat + Raykat Start mixture in the 3-5 leaf phase, the leaf area was 42.8 thousand $\mathrm{m}^{2}$ / ha. In the variant of seed treatment with the mixture Risotorphine + Raykat Start and the use of the micronutrient mixture Megamix Profi with the double-treatment of crops of 3-5 leaves + budding during the vegetation, the leaf area was 43.1 thousand $\mathrm{m}^{2}$ / ha, while the seeds were treated with Raykat Start with treatment by Kelik Mix during the growing season in the budding phase, the leaf area was 45.1 thousand $\mathrm{m}^{2} /$ ha.

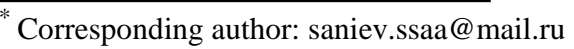


Table 3. The area of soybean leaves depending on the pre-sowing seeds treatment and treatment during vegetation with preparations in 2016-2018. thousand $\mathrm{m}^{2} /$ ha

\begin{tabular}{|c|c|c|c|c|c|}
\hline \multirow{2}{*}{$\begin{array}{c}\text { Seed } \\
\text { treatment }\end{array}$} & \multicolumn{2}{|c|}{ Treatment during vegetation } & \multirow{2}{*}{ Blooming } & \multirow{2}{*}{ Bean formation } & \multirow{2}{*}{ Green ripeness } \\
\hline & Preparations & Treatment period & & & \\
\hline \multirow{10}{*}{ 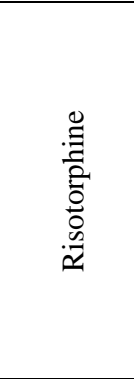 } & Without treatment & & 47.1 & 36.8 & 26.6 \\
\hline & \multirow{3}{*}{ Kelik Mix } & 3-5 leaves & 43.7 & 40.1 & 25.8 \\
\hline & & 3-5 leaves+budding & 46.4 & 38.6 & 33.1 \\
\hline & & budding & 45.4 & 40.0 & 30.2 \\
\hline & \multirow{3}{*}{$\begin{array}{c}\text { Aminocat }+ \text { Raykat } \\
\text { Growth }\end{array}$} & 3-5 leaves & 50.0 & 42.8 & 34.5 \\
\hline & & 3-5 leaves+budding & 44.7 & 37.7 & 34.3 \\
\hline & & budding & 49.5 & 39.9 & 35.6 \\
\hline & \multirow{3}{*}{ Megamix Profi } & 3-5 leaves & 52.4 & 37.7 & 31.6 \\
\hline & & 3-5 leaves+budding & 45.6 & 37.8 & 35.3 \\
\hline & & budding & 48.2 & 38.5 & 30.8 \\
\hline \multirow{10}{*}{ 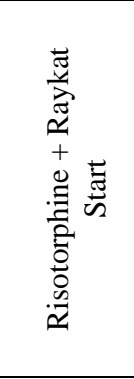 } & Without treatment & & 46.9 & 38.2 & 31.9 \\
\hline & \multirow{3}{*}{ Kelik Mix } & 3-5 leaves & 47.8 & 36.7 & 29.3 \\
\hline & & 3-5 leaves+budding & 44.6 & 39.7 & 32.1 \\
\hline & & budding & 47.9 & 37.7 & 35.1 \\
\hline & \multirow{3}{*}{$\begin{array}{c}\text { Aminocat }+ \text { Raykat } \\
\text { Growth }\end{array}$} & 3-5 leaves & 48.4 & 41.6 & 31.7 \\
\hline & & 3-5 leaves+budding & 44.3 & 41.3 & 36.2 \\
\hline & & budding & 43.8 & 38.1 & 30.5 \\
\hline & \multirow{3}{*}{ Megamix Profi } & 3-5 leaves & 53.1 & 42.8 & 32.9 \\
\hline & & 3-5 leaves+budding & 44.8 & 43.1 & 36.3 \\
\hline & & budding & 48.2 & 36.3 & 32.3 \\
\hline \multirow{10}{*}{ 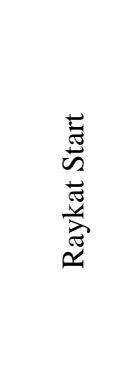 } & Without treatment & & 45.0 & 36.9 & 30.2 \\
\hline & \multirow{3}{*}{ Kelik Mix } & 3-5 leaves & 45.8 & 38.7 & 32.6 \\
\hline & & 3-5 leaves+budding & 48.3 & 42.1 & 33.0 \\
\hline & & budding & 47.4 & 45.1 & 32.8 \\
\hline & \multirow{3}{*}{$\begin{array}{c}\text { Aminocat }+ \text { Raykat } \\
\text { Growth }\end{array}$} & 3-5 leaves & 47.6 & 37.3 & 30.1 \\
\hline & & 3-5 leaves+budding & 50.3 & 39.3 & 31.9 \\
\hline & & budding & 52.5 & 35.5 & 33.1 \\
\hline & \multirow{3}{*}{ Megamix Profi } & 3-5 leaves & 42.7 & 37.7 & 29.6 \\
\hline & & 3-5 leaves+budding & 43.5 & 36.1 & 34.8 \\
\hline & & budding & 47.1 & 39.3 & 34.8 \\
\hline
\end{tabular}

In the phase of green ripeness, the total level of leaf area decreases significantly. The largest leaf area is formed after pre-sowing treatment of seeds with Risotorphine and the mixture Risotorphine + Raykat Start, with the double-treatment of crops by Megamix Profi in the phase of 3-5 leaves + budding and has an indicator of 35.6 and 36.3 thousand $\mathrm{m}^{2} /$ ha.

The accumulation of an organic mass of crops directly depends on the capacity of the leaf apparatus or photosynthetic potential. Studies have shown that during seedlings - flowering period, soybean forms a high level of this indicator and holds it without a sharp decrease to the phase of the bean formation and the phase of green ripeness.

The treatment of seeds with stimulants increases the value of the photosynthetic potential (PP) of crops under the influence of biostimulants. The average PP value over three years was in the range of $2.12-2.53$ million $\mathrm{m}^{2}$ / ha days (Table 4).

On average, for three years of research, we noted the highest total photosynthetic potential in the variant with pre-sowing seed treatment with Risotorphine + Raykat Start with the treatment of crops with Megamix Profi in the 3-5 phase of leaves 2.53 million $\mathrm{m}^{2} /$ ha.

Our studies revealed that soybean crops had the formation of a high level of photosynthetic potential, and showed a low rate of accumulation of dry organic matter with an indicator of the net productivity of photosynthesis. In the initial period, seedlings flowering indicator was at a low level (1.2-1.9 $\mathrm{g} / \mathrm{m}^{2}$ per day), but then by the bean formation - green ripeness period, this indicator increased to $4.03-4.27 \mathrm{~g} / \mathrm{m}^{2}$ per day.

Comparing three years, we can say that in the variants with the use of Risotorphin and Raykat Start preparations in the pre-sowing treatment, the leaves work more productively, especially after doubletreatment the crops in the phase of 3-5 leaves + budding with the micronutrient mixture Megamix Profi. In the variant with seed inoculation of Risotorphiny and Raykat Start and the use of Megamix Profi in the budding phase, this indicator was $3.20 \mathrm{~g} / \mathrm{m}^{2}$ per day (Table 4).

Extremely cold weather conditions in 2016-2017 did not allow soybean crops to form a high crop. In 2016 the maximum yield reached only $0.99 \mathrm{c} /$ ha in the option with a double-treatment of crops with Megamix Profi in the phase of 3-5 leaves + budding. The same trend was in 2017, with yield slightly higher than $1.24 \mathrm{~kg} / \mathrm{ha}$.

The weather conditions in 2018 were more favourable for the development of plants and the formation of a soybean crop. The level of productivity was in the range of $1.48-1.98 \mathrm{t} / \mathrm{ha}$.

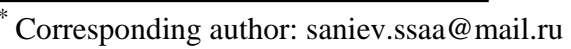


Table 4. Photosynthetic potential and net photosynthetic productivity depending on the pre-sowing seeds treatment and treatment during vegetation with preparations in 2016-2018. million $\mathrm{m}^{2} /$ ha days.

\begin{tabular}{|c|c|c|c|c|}
\hline \multirow{2}{*}{$\begin{array}{c}\text { Seed } \\
\text { treatment }\end{array}$} & \multicolumn{2}{|c|}{ Treatment during vegetation } & \multirow{2}{*}{$\begin{array}{l}\text { Photosynthetic potential. } \\
\text { million } \mathrm{m}^{2} / \text { ha per days }\end{array}$} & \multirow{2}{*}{$\begin{array}{l}\text { The net productivity of } \\
\text { photosynthesis. } \mathrm{g} / \mathrm{m}^{2} \text { per } \\
\text { day }\end{array}$} \\
\hline & Preparations & Treatment period & & \\
\hline \multirow{10}{*}{ 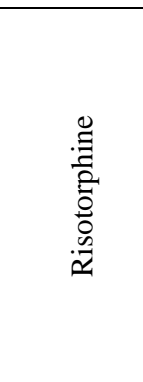 } & Without treatment & - & 2.25 & 2.27 \\
\hline & \multirow{3}{*}{ Kelik Mix } & 3-5 leaves & 2.16 & 2.49 \\
\hline & & 3-5 leaves+budding & 2.27 & 2.45 \\
\hline & & budding & 2.24 & 2.48 \\
\hline & \multirow{3}{*}{$\begin{array}{c}\text { Aminocat }+ \\
\text { Raykat Growth }\end{array}$} & 3-5 leaves & 2.50 & 1.99 \\
\hline & & 3-5 leaves+budding & 2.24 & 2.49 \\
\hline & & budding & 2.38 & 2.23 \\
\hline & \multirow{3}{*}{ Megamix Profi } & 3-5 leaves & 2.40 & 2.39 \\
\hline & & 3-5 leaves+budding & 2.27 & 2.68 \\
\hline & & budding & 2.29 & 2.57 \\
\hline \multirow{10}{*}{ 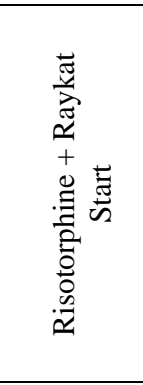 } & Without treatment & - & 2.28 & 2.44 \\
\hline & \multirow{3}{*}{ Kelik Mix } & 3-5 leaves & 2.24 & 2.61 \\
\hline & & 3-5 leaves+budding & 2.23 & 2.71 \\
\hline & & budding & 2.30 & 2.58 \\
\hline & \multirow{3}{*}{$\begin{array}{c}\text { Aminocat }+ \\
\text { Raykat Growth }\end{array}$} & 3-5 leaves & 2.39 & 2.37 \\
\hline & & 3-5 leaves+budding & 2.29 & 3.00 \\
\hline & & budding & 2.15 & 2.95 \\
\hline & \multirow{3}{*}{ Megamix Profi } & 3-5 leaves & 2.53 & 2.28 \\
\hline & & 3-5 leaves+budding & 2.35 & 2.69 \\
\hline & & budding & 2.26 & 3.22 \\
\hline \multirow{10}{*}{ 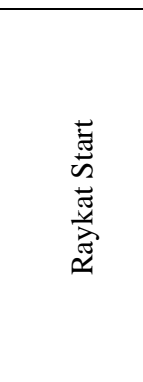 } & Without treatment & - & 2.21 & 2.66 \\
\hline & \multirow{3}{*}{ Kelik Mix } & 3-5 leaves & 2.26 & 2.46 \\
\hline & & 3-5 leaves+budding & 2.42 & 2.68 \\
\hline & & budding & 2.22 & 2.85 \\
\hline & \multirow{3}{*}{$\begin{array}{l}\text { Aminocat + } \\
\text { Raykat Growth }\end{array}$} & 3-5 leaves & 2.25 & 2.88 \\
\hline & & 3-5 leaves+budding & 2.36 & 2.77 \\
\hline & & budding & 2.37 & 2.95 \\
\hline & \multirow{3}{*}{ Megamix Profi } & 3-5 leaves & 2.12 & 2.55 \\
\hline & & 3-5 leaves+budding & 2.15 & 3.03 \\
\hline & & budding & 2.31 & 2.97 \\
\hline
\end{tabular}

We revealed that in favourable weather conditions the yield of options with only seed treatment turned out to be the same. It is $1.48 \mathrm{t} /$ ha for seed treatment Risotorphine, $1.51 \mathrm{t} /$ ha Risotorphine + Raykat Start, $1.53 \mathrm{t} /$ ha with one preparation Raykat Start (Table 5).

However, the average for three years of research shown that the treatment of crops with stimulating preparations significantly affected the level of productivity.

On average, for all variants of the preparation for vegetation period, seed treatment with Risotorphine provided a yield of $1.11 \mathrm{t} / \mathrm{ha}$, seed treatment with a mixture of Risotorphine + Raykat Start and the treatment option with Raykat Start increased yields to 1.20 and $1.23 \mathrm{t} / \mathrm{ha}$, providing a statistically significant increase.

On average of three years of research, all preparations for vegetation provide a reliable increase compared with the control. So, if in the control variant of seed treatment with Risotorphine, the yield was $0.99 \mathrm{t} /$ ha, in the variant of seed treatment with preparations, the yield was in the range of $1.10-1.17 \mathrm{t} / \mathrm{ha}$.

In seed treatment with Risotorphine + Raykat Start in the control, it was $1.08 \mathrm{t} / \mathrm{ha}$, when treating crops, it amounted to $1.20-1.24 \mathrm{t} / \mathrm{ha}$, when treating seeds with Raykat Start, they amounted to $1.10 \mathrm{t} / \mathrm{ha}$ and 1.21- 1.29 $\mathrm{t} /$ ha.

As for the timing of crops treatment, the best option was a double-treatment with Megamix Profi in the 3-5 leaf phase and the budding phase. This option provided a yield of $1.31 \mathrm{t} /$ ha for pre-sowing seed treatment with the mixture Risotorphine + Raykat Start and $1.40 \mathrm{t} / \mathrm{ha}$ after seed treatment with Raykat Start. 
Table 5. Soybean yield depending on the pre-sowing seeds treatment and treatment during vegetation with preparations in 2016-2018 $\mathrm{t} / \mathrm{ha}$

\begin{tabular}{|c|c|c|c|c|c|c|c|c|}
\hline \multirow{3}{*}{$\begin{array}{c}\text { Seed } \\
\text { treatme } \\
\text { nt }\end{array}$} & \multirow{3}{*}{ Preparations } & \multirow{3}{*}{$\begin{array}{l}\text { Treatment during } \\
\text { vegetation }\end{array}$} & \multicolumn{6}{|c|}{ Received from 1 ha } \\
\hline & & & \multicolumn{4}{|c|}{ In terms of treatment } & \multirow{2}{*}{$\begin{array}{c}\text { On } \\
\text { average } \\
\text { for seed } \\
\text { treatment }\end{array}$} & \multirow{2}{*}{$\begin{array}{c}\text { On } \\
\text { average } \\
\text { for crop } \\
\text { treatment }\end{array}$} \\
\hline & & & 2016 & 2017 & 2018 & average & & \\
\hline \multirow{10}{*}{ 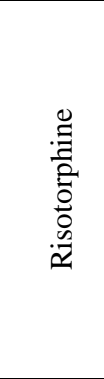 } & Without treatment & - & 0.73 & 0.76 & 1.48 & 0.99 & \multirow{10}{*}{1.11} & 0.99 \\
\hline & \multirow{3}{*}{ Kelik Mix } & 3-5 leaves & 0.78 & 0.84 & 1.56 & 1.06 & & \multirow{3}{*}{1.11} \\
\hline & & 3-5 leaves+budding & 0.90 & 0.98 & 1.66 & 1.18 & & \\
\hline & & budding & 0.74 & 0.91 & 1.58 & 1.08 & & \\
\hline & \multirow{3}{*}{$\begin{array}{l}\text { Aminocat }+ \\
\text { Raykat Growth }\end{array}$} & 3-5 leaves & 0.76 & 0.80 & 1.50 & 1.02 & & \multirow{6}{*}{1.17} \\
\hline & & 3-5 leaves+budding & 0.87 & 0.94 & 1.77 & 1.19 & & \\
\hline & & budding & 0.76 & 0.83 & 1.67 & 1.09 & & \\
\hline & \multirow{3}{*}{ Megamix Profi } & 3-5 leaves & 0.87 & 0.94 & 1.63 & 1.15 & & \\
\hline & & 3-5 leaves+budding & 0.89 & 0.98 & 1.70 & 1.19 & & \\
\hline & & budding & 0.84 & 0.96 & 1.69 & 1.17 & & \\
\hline \multirow{10}{*}{ 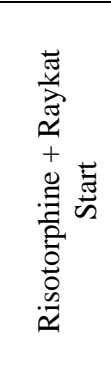 } & Without treatment & - & 0.85 & 0.87 & 1.51 & 1.08 & \multirow{10}{*}{1.20} & 1.08 \\
\hline & \multirow{3}{*}{ Kelik Mix } & 3-5 leaves & 0.86 & 0.94 & 1.64 & 1.15 & & \multirow{3}{*}{1.20} \\
\hline & & 3-5 leaves+budding & 0.89 & 0.99 & 1.84 & 1.24 & & \\
\hline & & budding & 0.88 & 0.96 & 1.80 & 1.21 & & \\
\hline & \multirow{3}{*}{$\begin{array}{c}\text { Aminocat }+ \\
\text { Raykat Growth }\end{array}$} & 3-5 leaves & 0.84 & 0.96 & 1.71 & 1.17 & & \multirow{6}{*}{1.24} \\
\hline & & 3-5 leaves+budding & 0.86 & 0.99 & 1.80 & 1.23 & & \\
\hline & & budding & 0.86 & 0.95 & 1.87 & 1.20 & & \\
\hline & \multirow{3}{*}{ Megamix Profi } & 3-5 leaves & 0.88 & 0.96 & 1.68 & 1.17 & & \\
\hline & & 3-5 leaves+budding & 0.90 & 1.11 & 1.91 & 1.31 & & \\
\hline & & budding & 0.87 & 0.97 & 1.84 & 1.23 & & \\
\hline \multirow{10}{*}{ 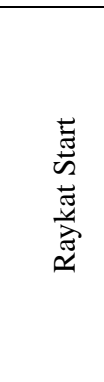 } & Without treatment & - & 0.88 & 0.90 & 1.53 & 1.10 & \multirow{10}{*}{1.23} & 1.10 \\
\hline & \multirow{3}{*}{ Kelik Mix } & 3-5 leaves & 0.84 & 0.93 & 1.69 & 1.15 & & \multirow{3}{*}{1.21} \\
\hline & & 3-5 leaves+budding & 0.94 & 1.12 & 1.77 & 1.28 & & \\
\hline & & budding & 0.84 & 0.94 & 1.79 & 1.19 & & \\
\hline & \multirow{3}{*}{$\begin{array}{c}\text { Aminocat }+ \\
\text { Raykat Growth }\end{array}$} & 3-5 leaves & 0.89 & 0.92 & 1.76 & 1.19 & & \\
\hline & & 3-5 leaves+budding & 0.88 & 0.98 & 1.85 & 1.24 & & 1.22 \\
\hline & & budding & 0.85 & 0.96 & 1.84 & 1.22 & & \\
\hline & \multirow{3}{*}{ Megamix Profi } & 3-5 leaves & 0.90 & 0.98 & 1.78 & 1.22 & & \multirow{3}{*}{1.29} \\
\hline & & 3-5 leaves+budding & 0.99 & 1.24 & 1.98 & 1.40 & & \\
\hline & & budding & 0.89 & 1.10 & 1.79 & 1.26 & & \\
\hline
\end{tabular}

$\begin{array}{cccccccc}\text { LSD } & \text { Av. } & \text { A } & \text { B } & \text { C } & \text { AB } & \text { AC } & \text { BC } \\ 2016 & 0.052 & 0.025 & 0.022 & 0.027 & 0.035 & 0.033 & 0 . .032 \\ 2017 & 0.061 & 0.040 & 0.045 & 0.041 & 0.049 & 0.052 & 0.050 \\ 2018 & 0.114 & 0.143 & 0.170 & 0.131 & 0.156 & 0.182 & 0.210\end{array}$

\section{Discussion}

Soybean crops have a good indicator of full germination and preservation reaching $62.03-63.31 \%$.

The maximum area of soybean leaves is formed in the flowering phase. In the variant of seed treatment with the mixture of Risotorphine and Raykat Start preparations, when treating crops with the microfertilizer mixture Megamix Profi, it reaches 53.1 thousand $\mathrm{m}^{2} /$ ha.

\section{Conclusion}

All variants of preparations for vegetation provide a reliable increase in yield compared with the control and provides a yield of $1.10-1.17 \mathrm{t} /$ ha when treating seeds with Risotorphine, 1.20 - $1.24 \mathrm{t} /$ ha when treating seeds by Risotorphine and Raykat Start preparations, 1.21$1.29 \mathrm{t} /$ ha when treating seeds with Raykat Start.

Soybean crops after the double-treatment with Megamix Profi in the phase of 3-5 leaves + budding has yields of $1.31-1.40 \mathrm{t} / \mathrm{ha}$ and reach maximum productivity.

\section{References}

1. S.V. Agafonova, Bulletin of the International Academy of Refrigeration, 2, 79-85 (2019)

2. V.G. Vasin, Research Journal of Pharmaceutical, Biological and Chemical Sciences, 5(9), 1230-1241 (2018)

3. F. Mutlu, S. Bozcuk, Hacettepe J. Biol. \& Chem., 41(4), 331-339 (2013)

4. V.Yu. Frolov, International Scientific and Practical Conference "World science", 1, 5(9), 68-71 (2016) 
5. G.T. Balakai, Scientific journal of the Russian Research Institute of Land Reclamation Problems, 3(35), 80-97 (2019)

6. S.V. Zharkova, Bulletin of Altai State Agrarian University, 6(176), 63-67 (2019)

7. E.V. Zasorina, Bulletin of the Kursk State Agricultural Academy, 6, 59-65 (2019)

8. O.V. Kayukova, Bulletin of the Chuvash State Agricultural Academy, 1(8), 31-35 (2019)
9. E.A. Krasnova, Agrarian Bulletin of the Urals, 5(184), 4-8 (2019)

10. E.S. Statsenko, Bulletin of the South Ural State University. Series: Food and Biotechnology, 3(7), 31-40 (2019)

11. A.V. Hainovsky, Bulletin of the Perm Institute of the Federal Penitentiary Service of Russia, 3(34), 84-88 (2019)

12. A.S. Dorokhov, Bulletin of the Ulyanovsk State Agricultural Academy, 3(47), 25-33, (2019) 